\title{
Water Resource Policy Analysis and Stakeholder Involvement in Water Security
}

\author{
Rismanitia Pertamsari ${ }^{1}$, Adis Imam Munandar ${ }^{2}$ \\ ${ }^{1}$ School of Strategic and Global Studies, Universitas Indonesia. Jl. Salemba Raya, DKI Jakarta 10430, Indonesia \\ ${ }^{2}$ School of Strategic and Global Studies, Universitas Indonesia. Jl. Salemba Raya, DKI Jakarta 10430, Indonesia \\ Corresponding Author: rismanitia.pertamasari@ui.ac.id
}

\begin{tabular}{|c|c|}
\hline Article Info & \\
\hline $\begin{array}{l}\text { Keyword: } \\
\text { Water Security; } \\
\text { Policy Analysis; } \\
\text { Stakeholder. }\end{array}$ & $\begin{array}{l}\text { Abstract: In accordance with the ratification of the Water Resource Law, which } \\
\text { was established after Law Number } 7 \text { of } 2004 \text { is canceled by the Constitutional } \\
\text { Court in } 2015 \text {, water has now becoming fully controlled by the state through the } \\
\text { Law no. } 17 / 2019 \text { concerning Water Resource Law. The identification of emerging } \\
\text { interests on who would advantage from the use of water are not only coming from } \\
\text { the communities but also from the various stakeholders. The method used in this } \\
\text { journal is theoretical qualitative as basis for discussion and analysis. The purpose } \\
\text { of this journal is to examine thoroughly the part of the policy which addressing } \\
\text { water compliance, water security with an increasing threat on water crimes and } \\
\text { water conflicts and involving stakeholders in enforcing the sustainability of water } \\
\text { management upon the enactment of the latest Water Resource law. }\end{array}$ \\
\hline
\end{tabular}

Kata Kunci:

Pemangku Kepentingan; Keamanan Air; Analisa Kebijakan.

\begin{abstract}
Abstrak: Terkait dengan pengesahan RUU SDA 2019 yang dibuat setelah UU nomor 7 tahun 2004 tentang SDA yang dibatalkan oleh Mahkamah Konstitusi pada tahun 2015, air kini menjadi sepenuhnya dikuasai oleh negara dan disahkan melalui UU Sumber Daya Air tahun 2019. Berbagai isu yang muncul adalah mengenai hak guna air yang memunculkan kepentingan tidak hanya dari komunitas setempat, tapi juga dari berbagai pemangku kepentingan. Metode yang digunakan didalam jurnal ini adalah kualitatif teoritikal sebagai dasar pengumpulan data dan analisa. Tujuan dari jurnal ini adalah untuk menganalisa bagian dari kebijakan UU SDA 2019 yang menyematkan kewajiban seluruh individu terhadap kepatuhan penggunaan air, menjaga ancaman keamanan air dan melibatkan para pemangku kepentingan dalam menegakkan hukum tentang keberlanjutan pengelolaan air setelah diberlakukannya UU SDA 2019.
\end{abstract}

\section{INTRODUCTION}

Water is an abundant natural resource found in the earth's surface. It is a very important natural resource requires by each form of living creatures. For humans itself, the need for water is absolute because most of the substances that make up the human body consist of water, and life can sustain due to the availability of sufficient water. According to Index Mundi, Indonesia ranks number 7 in renewable internal freshwater resources as totaling 2,019 billion cubic meters after Colombia and China. This includes consideration of internal river flows and groundwater from rainfall (AQUASTAT, 2020; IndexMundi, 2020). The utilization of water resources in Indonesia is still believed not evenly distributed to this date. Seasonal variations and spatial imbalances could also contribute to the water resource availability in Indonesia.

In the rainy season, some parts of Indonesia are experiencing enormous abundance of water which results in floods and other damage while dry season causes water shortages and 
drought resulting in disaster in some areas. Another fundamental problem is the limited numbers of water that can be explored and consumed, while Indonesia's growing population causes some drastic demands for water makes water quality problems increasingly narrowing the alternative for water sources that can be harnessed by the community (Samekto \& Winata, 2010). It could give possibilities that Indonesia is at risk of being threatened by expanding water crisis near in the future. As an addition, the long-term pandemic of COVID-19 could have worsened the people's need on water as water plays important role in preserving hygienes. In 2025, International Water Institute reported that Java and other islands of Indonesia are facing the risk as water crisis regions due to the classical reason that high number of population is the main cause of the watersupply deficit. The land conversion from agricultural function and forest to other forms of industrial uses has been increasing, causing the water resource subsided.

In average, there are about 50,000 hectares of agricultural lands converted into nonagricultural lands yearly and degradation of watershed area has been increasing from year to year as the changes in land-use from agriculture to non-agriculture causing the shrinkage of forestry area for its intensity on land utilization and the decrease in soil and water conservation (Kardono, 2018). This creates conditions that intensively increase degradation resulting in the natural disasters such as flood, drought, pollution, eutrophication and sedimentation (Kardono, 2018).

The clean water provision in Indonesia has always been referred to The 1945 Constitution of The Republic of Indonesia, Article 33 Paragraph (3) which reads "The earth, water and its natural resources contained therein are controlled by the state and used for the greatest prosperity of the people". This constitution is perceived as a social contract between the government and its citizens. This is further emphasized in Law No. 23 of 2014 concerning Regional Government, with the fulfillment of clean water for the community is one of the responsibilities of the government and regional governments as part of public services that they must do. The provision of clean water in Indonesia, in terms of quantity, quality, and continuity could have caused a clean water crisis which may lead to social conflict, if the supply of clean water does not grow in balance with the growth of population.

One of the programs established by the Central Government in the provision of clean water is the National Program for Water Supply and Community Based Sanitation or PAMSIMAS (Program Nasional Penyediaan Air Minum dan Sanitasi Berbasis Masyarakat) due to the government still see problems where some part of rural areas are not being facilitated or gotten advantage from having clean water supplies. On PAMSIMAS program, the central government plays role in selecting the region or city that will participate in the program, and district government will select targeted villages with the establishment of PAMSIMAS program. The PAMSIMAS budget is taken from the national state budget (APBN), region state budget (APBD), and with particular program assistance from external organization (e.g. World Bank and/or AUSAid, as well as community participation funds).

MK Decree (Contitutional Court Decree) No. 85 / PUU-XI / 2013 on February 18, 2015 has canceled Law No. 7 of 2004 concerning Water Resources, and re-enacting Law No. 11 of 1974 concerning Irrigation. Then the ratification of Water Resource Law number 17 of 2019 has completely revoked Law No. 11/1974 and declared invalid. The Law No. 17/2019 is overall to address state control and people's right on water, water resource management, permit, water resource's information system, empowerment and supervision, funding, civil society participation and investigation on criminal wrong-doings. In an increasing risk on water security, water resources need to be managed in a-way that every aspect is fulfilled for social, environmental and economic functions in harmony through synergy creation and integration between regions, sectors and generations to meet the people's demand for water. This law also explains how the existence of water as a source of community life, naturally, is dynamic and flows to a lower place without recognizing administrative boundaries.

The arrangement of authority and responsibilities for the Management of Water Resources by the Central Government, provincial governments, and district/city governments is based on the existence of the river basin. To achieve the integration of Water Resources management, a common reference for stakeholders in a river area needs to be drawn up in the form of Water 
Resources Management Patterns with the principle of integration between Surface Water and Groundwater, including the ones who would be responsible to safeguard water security from criminal wrong-doings.

This writing hopes to show the importance of presenting non-technical approaches in technically oriented water provision implementation, where conflicts about stakeholders deviating interest are less clear, but rather the objective of this journal is to examine thoroughly on the parts of the policy which address water compliance, water security and involving stakeholders in enforcing the law on the sustainability of water management upon the enactment of the latest Water Resource law.

A comprehensive conceptual framework which would allow analyzing the properties and the dynamics of complex water management and governance systems to develop appropriate strategies is lacking (Pahl-Wostl et al., 2010). Many problems in water management are more associated with governance failures than with the resource base (Pahl-Wostl, 2015). Developments in water management over the last few decades have seen changes in the role of three major social agents: government, market/economy (production, consumption), and civil society/community (individual citizens and organized groups outside of government and market, i.e. public voice) (Pahl-Wostl, 2015, Chapter 2).

Pahl-Wostl is also listing trends in water policy over the last few decades from the year of $60 \mathrm{~s}$ and 70s, where water policy was characterized with a strong role played by central government and central regulation, with hierarchical top-down command and control approach. Throughout these eras, most economic activities contribute to water management problem. Civil society was not having much participation in the governance but government failures to deliver adequate water services and to address increasing water problems, making the civil society had powers in mobilizing protest and voicing lack of satisfaction, even though they are still not a major player in shaping policy. In the late $80 \mathrm{~s}$ and $90 \mathrm{~s}$, the principles of subsidiarity, decentralization and privatization, and the market became a key instrument for water management, termed with a call on urban water supply and sanitation, while in the late $90 \mathrm{~s}$ and 2000s, there was an upsurge in participatory approaches, where central roles were delegated to community groups and water user associations, a shift that was similar to irrigation management.

\section{Indonesian Water Policy Brief Analysis}

Policy analysis provides information, evaluations, advice and advocacy for policy makers and is usually part of a naturalist or 'scientific' or positivist social science (Rhodes, 2018, Chapter 1). Analysis means deconstructing an object of study-that is, breaking it down into its basic elements to understand it better, and policy analysis is the examination of components of public policy, the policy process, or both, or in another way, it is the study of the causes and consequences of policy decisions (Kraft \& Furlong, 2018).

The Constitutional Court on February 18, 2015 has read out the case verdict Number 85/PUU-XI/2013, annulling all contents in Law Number 7 of 2004 on Water Resources. The Court also ruled that Law No. 11 of 1974 on irrigation will apply. Meanwhile, the ratification process of the 2019 Water Resouce Law was considered to be carried out in a rush and did not accommodate criticism of the formal process of the formation of legislation and did not substantially show the State's partiality towards the obligation to fulfill the people's right to water.

WALHI Institute, an environmental non-state actor organization, compared the latest Water Resouces Bill with Law Number 7 of 2004 concerning Water Resource which was overturned by the Constitutional Court in February 2015, and see that the law is only covers the interests of the people, but in substance it contains the continuity of investment in water resources that has destroyed the fulfillment of people's rights to water (Kumparan, 2019). The organization formulated 11 criticisms including preparing for legal action to prevent the impact of the Act which is considered detrimental to the community. The legal steps are taken to anticipate the loss of the environment and people after the bill is enacted and recorded in the state gazette: 
1. The formulation of norms for the recognition and protection of Masyarakat Hukum Adat/ MHA in Article 9 paragraph (3) is determined through a Regional Regulation. This regulation certainly does not learn from the factual conditions and the Constitutional Court's instructions which emphasize that "the inauguration of the customary law community must be interpreted as not constitutive, but declarative." Thus, the formulation should be regulated alternatively with due regard to factual conditions through the statement of a particular agency or through regional regulations or the decision of the regional head.

2. There is no clear and firm supervision mechanism. Article 56 paragraph (3) instead determines that supervision will be regulated further through a Government Regulation. It is clear that the oversight authority is more specific between ministries/institutions and the Regional Government;

3. The formulation of water conservation is still conservatory and refers to laws and regulations that do not accommodate the interests of local communities or indigenous peoples communally, the approach is still individual so that the potential for multiple interpretations and prone to be misused for criminalization (the arrangements can be considered in Article 24 to 27);

4. Institutionally, the Draft Bill does not specify specific Ministries/Agencies as leaders in the operationalization of management and other urgent matters related to natural resources. So there is a potential overlapping authority across Ministries/Agencies;

5. The permit on water resource utilization is treated equal to the licensing for establishing business in general, not having special permit on water business. Even the formulation limits people's innovations in water management, the potential for criminalization increases, especially for people who have not yet received government facilities (Article 44 and 45; Article 69);

6. Private doors and / or public private partnership schemes are opened, and formulation of licensing givess priorities for BUMN, BUMD and BUMDes. Any submission of further arrangements through Government Regulations has the potential to open up the opportunity for privatization of resources veiled water

7. Reducing affirmative action, by including conservation fees as part of the BJPSDA (Water Resources Management Service Fee).

8. Does not formulate the state supervision scheme and model in detail. Furthermore, the law does not regulate the provisions for evaluating existing licenses, whether it is still worth maintaining or not;

9. Formulation of people's participation and people's veto rights to permit the use of natural resources for water business needs are in an ambiguous manner. Participation in the management of water resources is only in the form of delivering aspirations, giving responses, without the right of rejection (Article 63 paragraph 3). Furthermore, the rejection of the permit is only given for private activities, not for licenses obtained by BUMN, BUMD and BUMDes. Furthermore, clarification of Article 51 redefines the word agreement by interpreting it as a result of the meeting without affirming the meaning of the agreement is to allow or not to permit in the community location. The rejection of private licensing has also been reduced by interpreting stakeholders as representatives of community groups, so that they are prone to being broadly interpreted and manipulated;

10. The law is only relying on the enforcement through criminal legal instruments, but does not explicitly regulate the resolution of disputes or violations of the law in detail in the civil scheme. No strict accountability scheme is formulated. In fact, there is almost no administrative law enforcement and supervision scheme formulated in the Bill (which has been changed into the Law). The formulation of criminal provisions is also prone to be used to criminalize the people;

11. Transitional provisions and closing provisions of this approved bill legalize the continuity of existing permits and privatization. The validity of the permits that existed before the bill was passed, but did not give orders to make adjustments to the new law. 
Although Indonesia has an average surface water availability that is relatively large by up to 25 times the world average, it does not mean that Indonesia has abundance of water which can be accessed by Indonesian societies (Pasandaran, 2015). The problem of drought that causes hunger and death on a large scale becomes a triggering factor for building reliable water resources management capabilities, as well as lack of strategy to improve people's welfare.

Seeing the role of private sectors in water management, water exploitation must be maintained in restrictions as part of effort to sustain water availability for the life of the nation as similar to the consideration of Constitutional Court upon cancelling Water Resource Law year 2004: (1) exploitation of water must not interfere, exclude, or even negate people's rights; (2) the state must fulfill the people's right to water, bearing in mind that people's access to water is a separate human right; (3) environmental preservation, because human rights must be safeguarded in the view of 1945 Constitution stating that, "everyone has the right to live physically and mentally well, live, and get a good and healthy environment and the right to health services"; (4) state supervision and control over water is absolute; and (5) the top priority given for exploitation of water is State-Owned Enterprises or Regional-Owned Enterprises. However, it is still possible for the Government to give permission to private businesses to operate on water by paying attention to the above restrictions (Pasandaran, 2015).

\section{The Policy Process Model}

The policy process model postulates a logical sequence of activities affecting the development of public policie which depicts the policymaking process and the broad relationships among policy actors within each stage of it, and the model can also be helpful to understand the flow of events and decisions in different cultures and institutional settings; in other words, the concepts and language are general enough to fit any political system and its policy processes (Kraft \& Furlong, 2018).

The policy process model can be set in six distincts reffering to initial Lasswell model. The term policy cycle can be used to make clear whether the process is cyclical or continuous, rather than a onetime set of actions. A top-down listing of each stage could be presented as a series of stages linked in a circle, because no policy decision or solution is ever final. Changing conditions, new information, formal evaluations, and shifting opinions often stimulate reconsideration and revision of established policies. Policies might be formulated before they are high on the political agenda, or it may be impossible to differentiate policy formulation from legitimation.

\section{Table.1 The Policy Process Models - Illustration is provided by the author}

\begin{tabular}{|c|c|c|}
\hline $\begin{array}{c}\text { Stage of The } \\
\text { Process }\end{array}$ & Definition & Illustration from Indonesian Perspectives \\
\hline $\begin{array}{l}\text { Agenda } \\
\text { setting }\end{array}$ & $\begin{array}{l}\text { How problems are perceived and } \\
\text { defined, command attention, and } \\
\text { get onto the political agenda. }\end{array}$ & $\begin{array}{l}\text { Health care reform rose sharply on the agenda } \\
\text { during COVID-19 pandemic and the New Normal } \\
\text { Era. For example, on the recent Climate Change } \\
\text { national conference, material related to national } \\
\text { policy on climate change control in the new normal } \\
\text { era, including mitigation action targets in several } \\
\text { sectors such as forestry, energy and adaptation } \\
\text { actions are presented. The learning from handling } \\
\text { the COVID-19 pandemic provides an overview of the } \\
\text { various considerations needed in preparing recovery } \\
\text { plans' towards "greener and more climate resilient } \\
\text { societies and economies" such as improving quality } \\
\text { of life, economic independence, environmental care, } \\
\text { environmental equality and gender equity. }\end{array}$ \\
\hline $\begin{array}{l}\text { Policy } \\
\text { formulation }\end{array}$ & $\begin{array}{l}\text { The design and drafting of policy } \\
\text { goals and strategies for achieving } \\
\text { them. Often involves the use of } \\
\text { policy analysis }\end{array}$ & $\begin{array}{l}\text { Policy formulation process for the establisment of } \\
\text { new autonomus regions in Indonesia which uses a } \\
\text { democratic governance perspective. }\end{array}$ \\
\hline
\end{tabular}


Table.1 (Continued) The Policy Process Models - Illustration is provided by the author

\begin{tabular}{|l|l|l|}
\hline \multicolumn{1}{|c|}{$\begin{array}{c}\text { Stage of The } \\
\text { Process }\end{array}$} & \multicolumn{1}{|c|}{ Definition } & \multicolumn{1}{|c|}{ Illustration from Indonesian Perspectives } \\
\hline $\begin{array}{l}\text { Policy } \\
\text { legitimation }\end{array}$ & $\begin{array}{l}\text { The mobilization of political } \\
\text { support and formal enactment } \\
\text { of policies. Includes } \\
\text { justification or rationales for } \\
\text { the policy action }\end{array}$ & $\begin{array}{l}\text { The provisions of the prosecution of illegal, } \\
\text { unreported and unregulated fishing (IUUF) in } \\
\text { international law and the legitimacy of the policy } \\
\text { action undertaken IUUF Indonesia in the } \\
\text { perspective of international law. }\end{array}$ \\
\hline $\begin{array}{l}\text { Policy } \\
\text { implementation }\end{array}$ & $\begin{array}{l}\text { Provision of institutional } \\
\text { resources for putting the } \\
\text { programs into effect within a } \\
\text { bureaucracy. }\end{array}$ & $\begin{array}{l}\text { Failing implementation of Government Law } \\
\text { number 74 year 2014 embodies in the } \\
\text { switchover of privately owned angkot public } \\
\text { transportation) become legal entity as public } \\
\text { transportation in Surabaya, Indonesia }\end{array}$ \\
\hline $\begin{array}{l}\text { Policy and } \\
\text { program } \\
\text { evaluation }\end{array}$ & $\begin{array}{l}\text { Measurement and assessment } \\
\text { of policy and program effects, } \\
\text { including success or failure. }\end{array}$ & $\begin{array}{l}\text { Efforts to measure the effectiveness of monetary } \\
\text { policy, such as interest rate issued by Bank of } \\
\text { Indonesia that set results from loosening liquidity } \\
\text { bylowering the benchmark interest rate }\end{array}$ \\
\hline Policy change & $\begin{array}{l}\text { Modification of policy goals and } \\
\text { means in light of new } \\
\text { information or shifting political } \\
\text { environment. }\end{array}$ & $\begin{array}{l}\text { security, and travel security reforms are adopted } \\
\text { following the COVID-19 Pandemic, and } \\
\text { subsequent changes were made in these areas } \\
\text { such as following the health protocol and } \\
\text { rapid/PCR testing to conduct domestic travel } \\
\text { with an airplane and others. }\end{array}$ \\
\hline
\end{tabular}

Sources: Drawn primarily from Charles O. Jones, An Introduction to the Study of Public Policy, 3rd ed. (Monterey, Calif:: Brooks/Cole, 1984); and Garry D. Brewer and Peter deLeon, The Foundations of Policy Analysis (Homewood, Ill.: Dorsey Press, 1983). The original policy process model can be traced to Harold Lasswell's early work on the policy sciences, "The Policy Orientation," in Daniel Lerner and Harold D. Lasswell, eds., The Policy Sciences (Stanford, Calif.: Stanford University Press, 1950).

\section{Monitoring Policy Outcomes}

Policy monitoring investigates relations between policy-program operations and their observed outcomes and becomes the primary sources of information about the success of efforts to implement policies (Dunn, 2014). According to Dunn, monitoring performs several functions including compliance, auditing, accounting, and explanation.

1. Compliance. Monitoring helps determine whether the actions of program managers are in compliance with norms, values, and standards mandated by legislatures, regulatory agencies, and professional associations. For example, the Environmental Protection Agency's Continuous Air Monitoring Program (CAMP) produces information about pollution levels to determine whether industries are complying with federal air quality standards.

2. Auditing. Monitoring helps discover whether resources and services intended for target groups and beneficiaries actually reach them, for example, recipients of social services or municipalities that qualify for federal and state grants. By monitoring federal revenue sharing, we can determine the extent to which funds are reaching local governments.

3. Accounting. Monitoring produces information that is helpful in accounting for social and economic changes that follow the implementation of policies. For example, the World Bank, the European Union, the United Nations, the United States, and other national and international bodies employ social and economic indicators to monitor changes in quality of life and well-being as measured by indicators such as average education, percentage of the population living below the poverty line, and average annual paid vacations.

4. Explanation. Monitoring also yields information that helps explain why the outcomes of public policies and programs differ. Whereas social indicators represent reasoning 
based on signs or symptoms, field experiments are designed to investigate whether policy-related and extra-policy factors are causally relevant to policy outcomes. The Campbell Collaboration, which has spread to more than 40 countries, is an archive of field experiments in education, labor, criminal justice, housing, social work, and other areas.

\section{Policy Actions and Outcomes}

Types of policy actions and policy outcomes are inputs, processes, outputs and impacts in three issues areas, which is criminal justice, municipal services and social welfare (Dunn, 2014). Policy outcomes are monitored because they are believed to enhance the satisfaction of some need; value, or opportunity - that is, outcomes are seen as ways to resolve a policy problem. At the same time, some policy outcomes are monitored because they may inhibit the satisfaction of some need, value, or opportunity (Sheldon \& Freeman, 1970). Many agencies regularly monitor policy outcomes and impacts by employing policy indicators in areas of health, education, housing, welfare, crime, and science and technology (MacRae, Duncan, 1986). Monitoring helps assess degrees of compliance, discover unintended consequences of policies and programs, identify implementation obstacles and constraints, and promote administrative accountability (Dunn, 2014).

\section{Criminal Provisions of Law No. 17 year 2019 on Water Resource}

Water Resource Law no. 17 year 2019 has two penalty provisions which are divided into crimes committed intentionally and crimes committed due to negligence. There are three provisions prevail upon the committed crimes are done on purpose. First, Article 68 of the Law states that everyone must not intentionally: a. Carry out activities that result in a disruption of the condition of the watershed, the damage to water sources and infrastructure, and/or water pollution; b. Conduct activities that cause water damage. Second, Article 69 states the type of criminal offense for anyone who intentionally: a. interfere with water conservation efforts; $b$. use water resources that cause damage to water sources and the environment or the surrounding public infrastructure; c. make use of Water Resources in the area of nature reserves and nature conservation areas; or d. conduct activities that cause damage to the infrastructure of water resources. Third, the provision of Article 70 states that anyone who intentionally: a. conduct construction and non-construction activities at water sources without obtaining permission from the Central Government or Regional Government; b. renting out or transferring part or all of the Permit to use Water Resources for non-business needs and permission to use Water Resources for business needs; or c. use water resources for business needs without permission.

Meanwhile, criminal acts that occur due to negligence include: First, Article 71 states the prohibition for anyone whom their negligence due to: a. carry out activities that result in disruption of the condition of the watershed, infrastructure, and / or water pollution as referred to in Article 24; or b. carry out activities that result in the occurrence of water damage as referred to in Article 36. Second, Article 72 states the prohibition for everyone whom their negligence due to: a. interfere with water conservation efforts; b. use water resources that cause damage to water sources and the environment or the surrounding public infrastructure; c. make use of Water Resources in the area of nature reserves and nature conservation areas; or $\mathrm{d}$. conduct activities that cause damage to the infrastructure of water resources. Third, the provisions of Article 73 confirm that everyone whom their negligence due to: a. carry out construction and non-construction activities at water sources without permission from the Central Government or Regional Government as referred to in Article 3 paragraph (3); or b. conduct the use of Water Resources for business needs without a permit as referred to in Article 46 paragraph (2), could be sentenced to a maximum imprisonment of three months and a maximum of six years and a fine of at least Rp. 300 million and a maximum of Rp. 1 billion.

In addition, Chapter 13 of the law article 67 regulates Investigation stating that:

1. Police officers of the Republic of Indonesia act as investigators but other than that, certain civil servant officials within government agencies whose scope of duties and responsibilities in the field of Water Resources are authorized as investigators as 
referred to in the Criminal Procedure Code to conduct investigations of Water Resources criminal offenses.

2. The civil service investigating official as referred to in paragraph (1) is authorized to:

- Conduct an examination of the truth of a report or information regarding a criminal act of water resources;

- Conduct examination of persons or business entities suspected of committing criminal acts in water resources;

- Summon people to be heard and examined as witnesses or suspects in water resources crime cases;

- Conduct an examination of Water Resources Infrastructure and stop equipment suspected of being used to commit a crime;

- Make arrests, detention and search;

- Sealing and / or confiscating tools for activities used to carry out criminal acts as evidence;

- Ask for expert assistance in the context of carrying out the task of investigating Water Resources criminal offenses;

- Make and sign the minutes and send them to the investigators of the Indonesian National Police; and/or

- Stop the investigation if there is not enough evidence or the event is not a criminal offense.

3. The civil service investigating officials as referred to in paragraph (2) notifies the commencement of the investigation to the investigator of the Republic of Indonesia National Police.

4. The civil service investigating officials as referred to in paragraph (2) submits the results of the investigation to the public prosecutor through the investigator of the Indonesian National Police in accordance with the Criminal Procedure Code.

5. The civil service investigation officials in exercising their authority as referred to in paragraph (2) is under the coordination and supervision of the investigators of the Indonesian National Police in accordance with the Criminal Procedure Code.

\section{Stakeholder Analysis}

Stakeholder analysis is added in this paper to assess who will likely to involve in the process of supervision and law enforcement after policy outcomes are seen through the policy implementation. We will see how actors, representing different levels of government, communities and water industries integrated into this process. The question is: who plays an important role, what interests are represented, and how are the affected actors represented? Traditionally, such questions could have been addressed through one of the methods taken for stakeholder analysis.

Freeman's definition of stakeholder means that any group of individual who can affect or is affected by the achievement of the organization's objectives (Freeman, 2015). Some types of entities which might include as stakeholders are persons, groups, neighborhoods, organizations, institutions, societies, and even the natural environment are generally thought to qualify as actual or potential stakeholders, because the view taken about the existence and nature of the stake that presents an area of argument, is upon the basis of "stake" that "what counts" is ultimately decided (Mitchell et al., 1997). Mitchell, Agle and Wood (1997) offered a theory of stakeholder identification and salience that suggests managers' perceptions having three key stakeholder attributes-power, legitimacy, and urgency - which affect stakeholder saliencethe degree to which managers give priority to competing stakeholder claims.

There is no individual organization theory offers systematic answers to questions about stakeholder identification and experience, although most such theories tell us much about the role of power or legitimacy (but not both) in stakeholder and manager relations. Using these three attributes, Mitchell, Agle and Wood (1997) developed a stakeholder classification with three qualitative stakeholder classes. Low class is identified by ownership or is associated with only one if attribute and it is called latent stakeholder. What is quite prominent among the 
stakeholder classes is identified by their ownership or ownership attributes of the two attributes and it is called prospective stakeholders. A very prominent class is identified by ownership of all the attributes and it is called the definitive stakeholder.

\section{RESEARCH METHOD}

The research method used in this journal is theoretical qualitative by sticking to data and using certain theories as a basis for data collection and data analysis. This is conducted in order to formulate results based on the given theory. This method provides a certain insight to strengthen the concept and understanding of water resources security.

\section{ANALYSIS AND DISCUSSION}

Although the 2019 water resource law is still fairly new, there are not many literatures which discuss the implementation of this new Water Resource policy in various regions. Many articles and journals before the new law took place, discuss about water resource by referring to the Law no. 7 year 2004, Law no. 11 year 1974 and President Decree no. 42 year 2008 on Sustainable Management of Water Resources.

Continuous water resource management research conducted at Sorong City, Papua, Indonesia where they studied on Integrated Water Resource Management program, Agroconservation development, River Restoration, disaster mitigation assessment using Flood Spatial Analysis and Physiography Characteristic and Wastewater Treatment Technologies. Problems are the decline in the quality and quantity of water resources in Sorong City that is caused by several factors, including: 1. Pollution/sedimentation of rivers in Sorong City, especially Remu River; 2. Damage to the forest/vegetation protective area from the water sources of the rivers in the City of Sorong, especially the Remu River; 3. Increasing activity of opening and using agricultural land that causes changes in the function of the catchment area of the rivers in the City of Sorong especially the Remu River (Pristianto, 2018).

In the U.S, water mis-management in Michigan where the residents began complaining about the taste, odour and colour of the water, but to little avail, and for nearly 18 months, they drank and bathed with improperly treated water that coursed through ageing pipes and fixtures, releasing toxic lead at levels well above the EPA's legal limit. Inequalities and injustice lie beneath this story of water contamination and water access in a city where nearly 60 percent of residents receive food stamps, where the median household income is 50 percent less than the state-wide figure and where 40 per cent of the residents live below the poverty line (Brisman et al., 2018).

In Bali, the implementation of Law No. 7/2004 on Water Resources has been intertwined with political economy of massive tourism development, including changes in water utilization dimensions from social, agriculture and environment functions with an emphasis on balance and harmony and toward economic functions with an emphasis on economic efficiency and added value. It showed that capitalist actors in water management and utilization for supporting the tourism sector have been expanding rapidly, induced water privatization and commercialization, which then causes water over exploitation, shortage in agricultural water, agricultural land conversion, declining the size of agricultural land and agricultural production, as well as farmers' income; so the water privatization and commercialization also causes institutional changes in the forms of subak marginalization in spatial space, autonomy and social cohesion norms, governance, leadership, power and authority (Tarigan \& Simatupang, 2016).

The overwhelming corpus of evidence suggests that privatizing previously state-owned and operated water facilities has resulted in increased costs and reduced quality to tax-paying consumers (Brisman et al., 2018). The commercial exploitation of scarcity will continue to see exorbitant profits for a small international membership of water barons at the social and economic expense of the millions of people living in increasingly water-stressed environments and the privatization of water has not increased access and reduced costs; it has achieved exactly the opposite (Brisman et al., 2018). The commodification of water has provided powerful corporate conglomerates with carte blanche (complete freedom) to exploit scarce water 
resources for maximum commercial gain, whilst all the time trumpeting a mantra of efficiency, equity and effectiveness (Brisman et al., 2018).

Currently, the on-going review on the draft of OMNIBUS Law, specifically on the Work Copyright Bill (RUU Cipta Kerja) is set to eliminate the role of Regional Governments in Managing Natural Resources concerning article 12 to 17 of Law No. 17/2019 on Water Resource (Bahfein et al., 2020). This could have marked on a great scale of society's participation on the governance of water resource in each of their regions.

\section{Water Crimes}

Water crimes is emerging global issues where it includes diverse types of crimes ranging from the pilfering of water from pipelines, illegal waste management, water theft, river and marine pollution, manipulation of sampling methods to avoid treatment costs, fraud and illegal trafficking of water, terrorism and cyber-attacks on water management operations, illegal waste discharges from factories, and unauthorised consumption from the water network (Eman et al., 2017). The uneven distribution of water around the world has led to the situation in which water theft is on the rise and the re-conceptualisation of water as a tradable commodity has increased its prices and placed it in fields of interest given the potential profit for organised crime (Eman et al., 2017).

There are eight further insight of different crimes against water (Barclay \& Bartel, 2015), namely: 1) water theft (including the pumping, impoundment or diversion of water from irrigation channels, river systems, dams or groundwater bores without a licence or in contravention of licence conditions that cause changes to flows and reduce water access to neighbouring farms, livestock and riparian zone management); 2) water contamination (industrial contamination, contamination due to depletion of underground and surface water sources, degradation of soil, contamination of surface and ground water through fertiliser/chemical or effluent run off from farm land, destruction of wildlife habitat, and reduction of biodiversity); 3) waterway diversion (referring to water theft through the illegal damming of waterways, filling of tankers and deep drilled water bores); 4) unauthorised taking of surface or ground water; 5) violation of water compliance and enforcement; 6) water-related corruption; 7) water-related terrorism; and 8) water-related consequences of other forms of illegal or unregulated activity (e.g. the impact of toxic chemicals and hazardous waste materials being swept up in flood waters and polluting freshwater systems, or the storage of legacy mining waste, stockpiling of tyres, repositories for chemical wastes and so on can be indirectly implicated in water-related crime insofar as how this occurs may violate relevant regulatory regimes and thus contribute to greater harm than might normally be expected).

These highlight the fact that it is very important for people who work in the law enforcement to have knowledge on the water crimes because the nature of the crime is hard to detect, investigate, prosecute and study. Previous case before the implementation of Law No. $17 / 2019$ is in 2014, where the Jambi Regional Police examined a property businessman work on PT. GPSP Company as a suspect in the violation of Water Resources Law no. 7/2004 (before it was cancelled in 2015) for building a shop along the river flow of Jambi City. The suspect was threatened with 5 years sentence. In carrying out the construction of the shop on Selincah River, the suspect did not secure a technical permit from the Jambi Province Public Works Department (Hukumonline, 2014).

Other case in Lombok, Gili Trawangan, the director of the PT Berkat Air Laut Water Management Company was named as a suspect in the misuse of Water Business Rights (Hak Guna Usaha Air/ HGUA) threatened with a two-year prison sentence with five million rupiah fine. The case was occured in 2017 and the criminal threat that was applied in the case of HGUA abuse is referring to the Law No. 11/1974 concerning Law Irrigation. In its rules, HGUA should not be interpreted as granting rights to control water resources, rivers, lakes or swamps. Instead, HGUA becomes an instrument of control used by the government to determine water rations that can be taken by the private sector. Evidences found in the case are assets in the form of ground water drilling machines and company warehouses located in the center of Gili Trawangan (Lawjustice.co, 2017). 


\section{Water Conflict}

Limited access to water in a region that is known to have abundant water resource can trigger conflicts. Water has been used as a weapon and an instrument of war (White, 2002). The pressures on the need of clean water due to rapid population growth, widespread environmental degradation, increased consumption and climate change. This pressure makes it even more urgent to find solutions how to avoid the tension that occurs due to water problems. At present, water security threats have to do with conflict, migration and food insecurity. The Indonesian government itself is expected to be able to assess these risks, illustrate security and draft laws and to strictly monitor the implementation of water policy and being enforced at all cost.

Implementation of local government regulation on spatial planning in Pandeglang Regency faced many obstacles, such as conflict between residents and companies in the Village Cadasari, Pandeglang Regency in 2017 (Hakim et al., 2017). The water crisis is actually related to demand and availability. When demand for water is very large but water supply is low, scarcity occurs. Water resources' consumers are divided into two, commercial users and non-commercials. Commercial water users are more expansive, ignoring the non-commercial communities that are traditionally more entitled (Rahardjanto, 2011). In this case, Pandeglang District Government failed to implement the spatial planning program because of its alignments with investors and their inconsistencies in implementing spatial policy. The exploitation of water resource was done by the companies using advance equipment and about 20 hectares of land set to be controlled by the companies with 8 water springs available around the villages in Pandeglang regency. All of these water springs have been used by the residents for decades for household (washing, bathing and drinking) and irrigation purposes.

\section{Analysis of Stakeholder Interests and Actors in Water Resources Crime and Conflict}

The first step to identify all the potential stakeholders and their interests; assess the likely impact of the project on each of these interests (positive, negative, unknown) and indicate the relative priority which the project should give to each stakeholder in meeting their interests (Overseas Development Administration, 1995). Participation matrix is developed to identify different stakeholders may wish to participate in different ways:

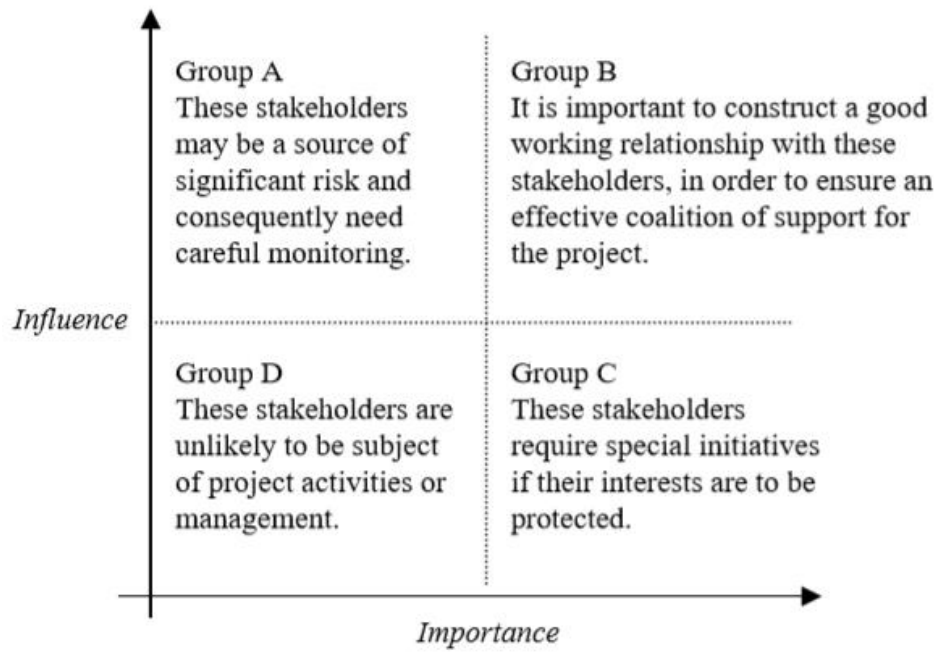

Figure.1 Matrix classification of stakeholders according to elative influence and importance Source: (Grimble \& Wellard, 1997)

Group A might include 'water mafia', illegal private companies exploiting water resources, rioter or insurgent, separatists (in conflicting areas) and other criminals. Group B is in the form of local government in the village, sub-districts and regency areas, local and/or regional owned enterprises, local law enforcer including Indonesian National Army, Indonesian Police, National Intelligence Agency operated in the appointed regions, infrastructure builder, water suppliers, Water Utilities Organization, law firms and others. Group C is important stakeholders such as 
customary leader even the local societies or people who inhabit their own areas where the water springs have naturally available. Their participations are needed to ensure that their villages are safely getting access to clean water. Group D is state auditors, Indonesian state finance and development survelliance committee civil investigators, the non-state actors such as Legal-Aid Institute, local non-government agencies or international agencies which could perform assistance in managing water resource or provides legal assistance for communities and others.

Other methodology developed in classification of stakeholders is to combine Mitchell et al. (1997) taxonomy which is latent stakeholders, expectant shareholders and definitive shareholders earned from the attributes of power, legitimation and urgency.

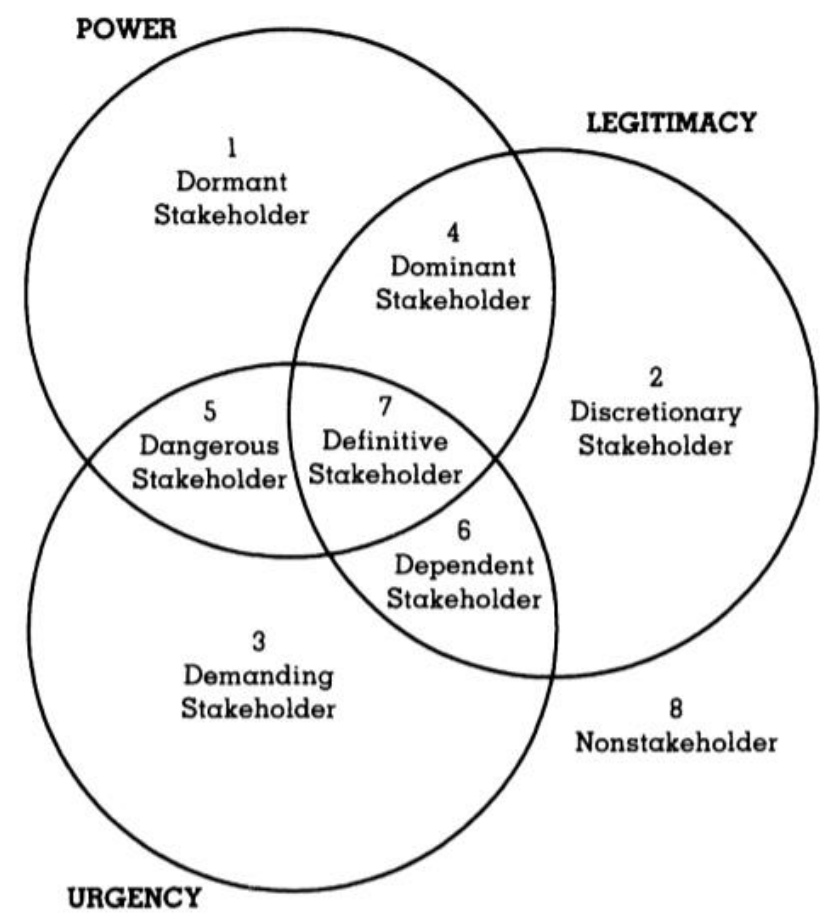

Figure.2 Illustration of Stakeholder Typology: One, Two, or Three Attributes Present Source: (Mitchell, et al, 1997)

Latent stakeholders constitute to power and legitimacy. The attributes lie in the Dormant Stakeholders, Discretionary Stakeholders and Demanding Stakeholders combined; who can spend a lot of money or who can command attention of the news media. These are including scholars, academicians and internal management of the companies. Expectant stakeholders establish legitimacy and urgency, with attributes in Dominant Stakeholders, Demanding Stakeholders and Dangerous Stakeholders. Definitive stakeholders constitute to any expectant stakeholder who can become a definitive stakeholder by acquiring the missing attribute.

The appropriate degree of involvement for the definitive stakeholders is active involvement (co-operating/co-working), because these stakeholders have a lot of power, legitimacy, urgency and they are close to the catchment area; in other words, they are the most important stakeholders and they should be involved at the highest level (Paola Sabina Lupo Stanghellini, 2010). The appropriate degree of involvement of the expectant stakeholders is the second stage of involvement (co-thinking); it means that these stakeholders should be consulted in order to gain useful information and opinions and the appropriate level of involvement for the latent stakeholders is the third stage of involvement (co-knowing); in other words they should be kept informed (P S Lupo Stanghellini \& Collentine, 2008). 
Table.2 Illustration of stakeholder analysis represented in relate to the enforcement of water law and minimizing water conflict (analysis is represented by the author)

\begin{tabular}{|c|c|c|c|c|c|c|c|c|}
\hline No & Involving stakeholders & Power & Legitimacy & Urgency & $\begin{array}{l}\text { Proximity } \\
\text { with the } \\
\text { water } \\
\text { source } \\
\end{array}$ & $\begin{array}{l}\text { High } \\
\text { Scores }\end{array}$ & Classification & $\begin{array}{l}\text { Level of } \\
\text { Involvement }\end{array}$ \\
\hline 1 & Local societies & 2.87 & 3.30 & 5.00 & 5.00 & 4 & Expectant & Co-thinking \\
\hline 2 & $\begin{array}{l}\text { State Government: Ministry } \\
\text { of Energy and Mineral } \\
\text { Resource }\end{array}$ & 3.75 & 2.20 & 3.50 & 1.63 & 2.77 & Definitive & Co-working \\
\hline 3 & $\begin{array}{l}\text { State Government: Ministry } \\
\text { of Environment }\end{array}$ & 4.00 & 3.45 & 4.10 & 2.00 & 3.38 & Definitive & Co-working \\
\hline 4 & $\begin{array}{l}\text { Regional Government } \\
\text { Institution - Environmental } \\
\text { Monitoring Agency }\end{array}$ & 3.78 & 4.88 & 3.67 & 4.67 & 4 & Definitive & Active \\
\hline 5 & $\begin{array}{l}\text { Local Government of } \\
\text { Provinces and top-down } \\
\text { administratives including } \\
\text { tourism institutions }\end{array}$ & 5.00 & 4.65 & 5.00 & 5.00 & 4 & Definitive & Active \\
\hline 6 & $\begin{array}{l}\text { Law enforcer: police, } \\
\text { military, civil investigator, } \\
\text { Commission of Corruption } \\
\text { Erradication }\end{array}$ & 5.00 & 5.00 & 5.00 & 4.90 & 4.9 & Definitive & Active \\
\hline 7 & $\begin{array}{l}\text { Association of agriculture } \\
\text { and/or fisheries, breeders, } \\
\text { etc. }\end{array}$ & 2.33 & 3.13 & 4.16 & 3.00 & 3 & Latent & $\begin{array}{l}\text { Information } \\
\text { supply }\end{array}$ \\
\hline 8 & $\begin{array}{l}\text { Non-government } \\
\text { institutions, international } \\
\text { NGO, UN, World Bank, } \\
\text { USAID, AUSAID, etc. } \\
\end{array}$ & 2.00 & 2.67 & 2.12 & 4.00 & 2.7 & Expectant & Consultation \\
\hline 9 & $\begin{array}{l}\text { Private water companies or } \\
\text { private water management } \\
\text { companies and local } \\
\text { suppliers or big suppliers. }\end{array}$ & 3.41 & 3.72 & 4.80 & 3.19 & 4 & Expectant & $\begin{array}{l}\text { Information } \\
\text { Supply }\end{array}$ \\
\hline 10 & $\begin{array}{l}\text { State-owned companies } \\
\text { Water and Regionally- } \\
\text { owned Water Institutions }\end{array}$ & 4.00 & 4.15 & 3.12 & 3.55 & 4 & Expectant & $\begin{array}{l}\text { Information } \\
\text { Supply }\end{array}$ \\
\hline 11 & $\begin{array}{l}D P R, D P R D, D P D \\
\text { (legislatives) }\end{array}$ & 3.78 & 4.00 & 2.15 & 2.87 & 3 & Latent & Co-knowing \\
\hline 12 & $\begin{array}{l}\text { National Intelligence } \\
\text { Organizations }\end{array}$ & 3.11 & 3.50 & 2.41 & 1.77 & 2.7 & Definitive & Active \\
\hline 13 & $\begin{array}{l}\text { Government Internal } \\
\text { Auditors }\end{array}$ & 4.00 & 4.00 & 4.00 & 3.00 & 3.8 & Definitive & Active \\
\hline
\end{tabular}

Source: (Lupo Stanghellini, 2007)

The implementation process of the stakeholder analysis methodology relating to the law enforcement can be performed by testing and running with a group of volunteers, but in this case, set of stakeholders presented by suppositions or theories. The list of stakeholders which can be found the sub-basin area consisted of government stakeholders, associations (farmers and fisheries associations, breeders, tourisms, and environment) and common land administrations. The calculation presented here is an estimate with the average score for each attribute of each stakeholder.

The stakeholders divided into three groups: definitive stakeholders (level of involvement: active or co-working); expectant stakeholders (level of involvement: consultation or co-thinking), latent stakeholders (level of involvement: information supply or co-knowing) (P S Lupo Stanghellini \& Collentine, 2008), with explanations as below:

Definitive stakeholders have three key attributes: power, interest (attention) and influence. Power is derived from 5 key sources: 1) relevant legal authority for decision-making and implementation, including rules and laws: 2) having up to date information to strive the interests of consumers; 3 ) having particular expertise in consumer protection based on not only the consumer law but also the consumer policy, planning and management; 4) take over the costs and resources to support the activities and 5) the ability to mobilize the masses to change the policy. Has Interest, which is interpreted as the degree on which stakeholders demand all the 
attention in the policy process (Kismartini \& Yusuf, 2015). State Government: Ministry of Energy and Mineral Resource and Ministry of Environment, Regional Government Institution Environmental Monitoring Agency, Local Government of Provinces and top-down administratives including tourism institutions, Law enforcer: police, military, civil investigator, Commission of Corruption Erradication, National Intelligence Organizations and Government Internal Auditors have the power to carry out, investigate and executing any violation related to water crimes. In addition, these stakeholders have roles as mediators to minimize water conflicts between societies and companies.

Expectant stakeholders' contributing attributes are influence, power and interest with 4 types of stakeholders involved; Dominant stakeholder, Dangerous stakeholder, Dependent stakeholder, Dormant stakeholder. Local societies, Non-government institutions, international NGO, UN, World Bank, USAID, AUSAID, Private water companies or private water management companies and State-owned companies and Regionally-owned companies could be the source of conflicts and crimes. Non-state actors' influence could either be very dangerous or beneficial considering their involvement towards conflicts and crimes. Take for an example, the role of WALHI institute as an actor to protest on the establishment of the new Law towards crime potential or conflicts between societies.

Latent stakeholders have influence and interest attributes with discretionary and demanding stakeholders involved. Associations in the region from farmers, breeder, fisheries, and tourism to the environmental protection have influences and private interests toward water utilization in their region. They can vocalize local citizens concern from the mis-management of water resource and the legislatives could hear the associations that can be put into their agenda or drafting changes in water laws.

\section{CONCLUSION}

The Law No. 17/2019 on Water Resource is to address state control and people's right on water, water resource management, permit, water resource's information system, empowerment and supervision, funding, civil society participation and investigation on criminal wrong-doings. In an increasing risk of water security, water resources need to be managed in a-way that every aspect is fulfilled for social, environmental and economic functions in harmony through synergy creation and integration between regions, sectors and generations to meet the people's demand for water. Water Resource Law no. 17 year 2019 has two penalty provisions which are divided into crimes committed intentionally and crimes committed due to negligence. Water crimes is emerging global issues where it includes diverse types of crimes, while Limited access to water in a region that is known to have abundant water resource can trigger conflicts. Based on the building analysis on stakeholders and the water law policy, it presents several perspectives and tools on how to achieve changes it needed by the policy maker and Indonesian law enforcer to the policy violators. Many people in Indonesia have lack access to safe and adequate drinking water and bear in mind that water crimes can affect water quality, water scarcity and water insecurity.

Qualitative approaches in this writing provide insight into the optimum stakeholder identification and it shows that it can't be delegated to engineers alone. Policy makers and implementing stakeholders need to create unconventional solutions at all levels and form a good coordination between others. Politicians will help to discuss on the regulation and media and the people will demand transparency and how their water is provided and managed. The government will also need the police, the civil investigators and state auditors to enforce justice towards water rights.

\section{REFERENCES}

AQUASTAT, F. and A. of the U. N. (2020). Indonesia Total internal renewable water resources (IRWR). Retrieved July 10, 2020, from http://www.fao.org/nr/water/aquastat/data/query/results.html

Bahfein, S., Alexander B, H., \& Kompas.com. (2020). RUU Cipta Kerja, Peran Pemda Mengelola SDA Dihilangkan. https://properti.kompas.com/read/2020/02/22/085233421/ruu-cipta- 
kerja-peran-pemda-mengelola-sda-dihilangkan?page=all

Barclay, E., \& Bartel, R. (2015). Defining environmental crime: The perspective of farmers. Journal of Rural Studies, 39, 188-198. https://doi.org/10.1016/j.jrurstud.2015.01.007

Brisman, A., Mcclanahan, B., South, N., Walters, R., \& Drake, D. H. (2018). Critical Criminological Perspectives Water, Crime and Security in the Twenty-First Century: Too Dirty, Too Little , Too Much. Palgrave Macmillan. https://doi.org/https://doi.org/ 10.1057/978-1-13752986-2

Dunn, W. N. (2014). Public Policy Analysis (Fifth Edit). Pearson Education Limited.

Eman, K., Kuhar, S., \& Meško, G. (2017). Water crimes and policing. Varstvoslovje, 19(2), 105119.

Freeman, R. E. (2015). Strategic management: A stakeholder approach. In Strategic Management: A Stakeholder Approach. https://doi.org/10.1017/CB09781139192675

Grimble, R., \& Wellard, K. (1997). Stakeholder methodologies in natural resource management: a review of principles, contexts, experiences and opportunities. Agricultural Systems, 55(2), 173-193. https://doi.org/https://doi.org/10.1016/S0308-521X(97)00006-1

Hakim, A. L., Kolopaking, L. M., Siregar, H., \& Putri, E. I. K. (2017). Perebutan Sumberdaya Air: Analisis Konflik dan Politik Tata Ruang. Sodality: Jurnal Sodiologi Pedesaan, Agustus 2017, 81-91. https://doi.org/10.22500/sodality.v5i2.17901

Hukumonline. (2014). Pengusaha Properti Diperiksa Terkait Pelanggaran UU SDA. https://www.hukumonline.com/berita/baca/lt538d81110c224/pengusaha-propertidiperiksa-terkait-pelanggaran-uu-sda/

IndexMundi. (2020). Indonesia - Renewable internal freshwater resources, total (billion cubic meters). $\quad$ Retrieved July 12, 2020, from https://www.indexmundi.com/facts/indonesia/indicator/ER.H2O.INTR.K3

Kardono, K. (2018). Condition of Water Resource in Indonesia and Its Environmental Technology. Jurnal Air Indonesia, 3(2). https://doi.org/10.29122/jai.v3i2.2331

Kismartini, \& Yusuf, M. (2015). Stakeholders Analysis: Managing Coastal Policy Implementation in Rembang District. Procedia Environmental Sciences, 23(Ictcred 2014), 338-345. https://doi.org/10.1016/j.proenv.2015.01.049

Kraft, M. E., \& Furlong, S. R. (2018). Public policy : politics, analysis, and alternatives. In Public policy: politics, analysis, and alternatives. https://doi.org/10.1017/CB09781107415324.004

Kumparan. (2019). Walhi Gugat UU Sumber Daya Air yang Baru Disahkan. https://kumparan.com/kumparannews/walhi-gugat-uu-sumber-daya-air-yang-barudisahkan-1rtZJSur3Md

Law-justice.co. (2017). Pengelola Air Gili Trawangan Terancam Dua Tahun. https://www.lawjustice.co/artikel/40325/pengelola-air-gili-trawangan-terancam-dua-tahun/

Lupo Stanghellini, P. S. (2007). A methodology for involving stakeholders in water management: implementation of the participatory model "CATCH" in Trentino. PhD Dissertation. Department of Economics, University of Trento, Trento, Italy.

MacRae, Duncan, J. (1986). Policy Indicators: Links Between Social Science and Public Debate. $\begin{array}{lllll}\text { Science, } \quad \text { Technology, } \quad \text { Human } & 98 .\end{array}$ https://doi.org/10.1177/027046768601100118

Mitchell, R. K., Agle, B. R., \& Wood, D. J. (1997). Toward a theory of stakeholder identification and salience: Defining the principle of who and what really counts. Academy of Management Review, 22(4), 853-886. https://doi.org/10.5465/AMR.1997.9711022105

Overseas Development Administration. (1995). Guidance note on stakeholder analysis for aid projects and programmes. 1-10. https://doi.org/10.1016/B978-0-12-415829-0.15006-3

Pahl-Wostl, C. (2015). Water governance in the face of global change: From understanding to transformation. Water Governance in the Face of Global Change: From Understanding to Transformation, 1-287. https://doi.org/10.1007/978-3-319-21855-7

Pahl-Wostl, C., Holtz, G., Kastens, B., \& Knieper, C. (2010). Analyzing complex water governance regimes: The Management and Transition Framework. Environmental Science and Policy, 13(7), 571-581. https://doi.org/10.1016/j.envsci.2010.08.006 
Pasandaran, E. (2015). Assessing Development History of Law on Irrigation Water and Water Resources. Forum Penelitian Agro Ekonomi, 33(1), 33-46. https://media.neliti.com/media/publications/69883-ID-menyoroti-sejarahperkembangan-undang-un.pdf

Pristianto, H. (2018). Pengelolaan Sumber Daya Air Yang Berkelanjutan Di Kota Sorong. https://doi.org/10.31227/osf.io/s4f2v

Rahardjanto, A. K. (2011). Studi Pendahuluan Model Pengelolaan Sumberdaya Air Partisipatif Akomodatif Guna Antisipasi Konflik Pembagian Air (Kasus Sumberawan Kecamatan $\begin{array}{llll}\text { Singosari Malang). Jurnal 13(2). } & \text { Salam, }\end{array}$ http://ejournal.umm.ac.id/index.php/salam/article/view/468

Rhodes, R. A. W. (2018). What Is Decentred Analysis? Narrative Policy Analysis, 1-21. https://doi.org/10.1007/978-3-319-76635-5_1

Samekto, C., \& Winata, E. S. (2010). Potensi Sumber Daya Air di Indonesia. Seminar Nasional Aplikasi Teknologi Penyediaan Air Bersih Untuk Kabupaten/Kota Di Indonesia.

Sheldon, E. B., \& Freeman, H. E. (1970). Notes on Social Indicators: Promises and Potential. Policy Sciences, 1(1), 97-111. http://www.jstor.org/stable/4531375

Stanghellini, P S Lupo, \& Collentine, D. (2008). Stakeholder discourse and water management? implementation of the participatory model CATCH in a Northern Italian alpine subcatchment. Hydrology and Earth System Sciences Discussions, European Geosciences Unio, 12(1), 317-331. www.hydrol-earth-syst-sci.net/12/317/2008/

Stanghellini, Paola Sabina Lupo. (2010). Stakeholder involvement in water management: The role of the stakeholder analysis within participatory processes. Water Policy, 12(5), 675694. https://doi.org/10.2166/wp.2010.004

Tarigan, H., \& Simatupang, P. (2016). Dampak Undang-Undang Sumber Daya Air terhadap Eksistensi Kelembagaan Subak di Bali. Analisis Kebijakan Pertanian, 12(2), 103. https://doi.org/10.21082/akp.v12n2.2014.103-117

White, F. (2002). Water: life force or instrument of war? The Lancet, 360, s29-s30. 